\title{
Ridging, a Mechanized Alternative to Mounding for Yam and Cassava Production
}

\author{
S. A. Ennin ${ }^{1 *}$, E. Otoo ${ }^{1}$ and F. M. Tetteh ${ }^{2}$ \\ ${ }^{1}$ CSIR-Crops Research Institute, P. O. Box 3785, Kumasi, Ghana \\ ${ }^{2}$ CSIR-Soil Research Institute, Academy Post Office, Kumasi, Ghana \\ *Corresponding author; E-mail: stella@cropsresearch.org
}

\begin{abstract}
A cassava seedbed preparation field study was established at Fumesua in the forest and Ejura in the forest-savanna transition agroecologies of Ghana in 2004/2005. The experimental design was split plot with three seed bed preparation methods as the main plots and three nitrogen rates as sub plots, with basal application of 45-90 kg ha-1 $\mathrm{P}_{2} 0_{5}-\mathrm{K}_{2} 0$ on the fertilized plots. A similar study was conducted on yam seedbed preparation in 2003/2004, with a $2^{3}$ factorial design. Cassava and yams on ridges resulted in highest root and tuber yields, on both Lixisols in the coastal and forest-savanna transition and Acrisols in the forest agro-ecologies. However, yam tuber yield on mounds was not statistically different from yields on ridges. Number of roots per plant was identified as a major contributory factor to the yield increase of cassava on ridges. Seed bed preparation method was, however, not an important determinant of cassava root yield at high rates of fertilizer application of 90-45-90 kg ha-1 $\mathrm{N}-\mathrm{P}_{2} 0_{5}-\mathrm{K}_{2} 0$. Planting on mounds resulted in slender, cylindrically shaped cassava roots and yam tubers, while ridging produced oblong shaped roots and tubers. Weeding and fertilizer application were easier on manual ridging than on manual mounds. The study points to ridging as a potential option to mounding for cassava and yam production, with the feasibility of mechanization of ridges to reduce drudgery associated with roots and tuber crop production in the West African sub-region.
\end{abstract}

\section{Introduction}

Yam and cassava are the major root crops produced and consumed in West Africa. Ghana, since the past decade, has ranked third in world yam production and sixth in world cassava production. Among the exported horticultural crops in Ghana yam ranks second to pineapple and contributes about $16 \%$ of the national Agricultural Gross Domestic Product (AGDP), with cassava contributing 22\%. Yam production has increased from 614,000 tonnes during 1979-1981 to 3, 892,000 tonnes in 2005, a 533.8\% increase, as a result of increase in area under production. Cassava production has also increased from 1,894,000 tonnes to 9,739,000 tonnes, representing $414.2 \%$ increase during the same period (FAOSTAT, 2006).

The increase in cassava production is a factor of increased area under production, the development and release of higher yielding varieties by scientific research efforts and, also, favourable government policy. Cassava has played a key role in the reduction of under-nourishment in Ghana and Nigeria, with cassava consumption increasing from 63-129 kg/person/year in Nigeria and from 126-232 kg /person/year in Ghana (FAO, 2000).

In Ghana, yam and cassava are among the major food consumed and together contributed $36 \%$ of the total dietary energy supply from 2001 to 2003, with maize contributing 12\% (FAOSTAT, 2006). The importance of yam and cassava to the Ghanaian economy can, therefore, not be over-emphasized. However, yam and cassava have seen very little improvement in their husbandry practices over time. All phases of cultivation are labour-intensive, causing the youth to shy away from their cultivation, and limiting the scale of production. For instance, land clearing, burning and land preparation for yam cultivation have been estimated to consume about $49 \%$ of the labour outlay for producing one hectare of ware yams, especially in the rain forest agroecology of Nigeria. In Ghana, yam is planted at random on manually constructed mounds $1-2 \mathrm{~m}$ apart, and cassava is planted usually on flat ground or on mounds 1-1.5 m apart, in rows or at random. In other parts of Africa (Coursey, 1967), yam may be planted 'on the flat', on mounds or ridges, or on raised beds; or they may be planted in trenches or holes.

In general, root and tuber crops do not produce satisfactory yields on compacted or shallow soils. Three objectives of seedbed preparation in root and tubers generally, therefore, are to (i) optimize infiltration, (ii) enhance rooting depth, and (iii) improve soil-water management (FAO, 2000). Currently, mounding is by far the most widespread, and in the West African yam agro-ecology mounding used to be almost universal in the past (Coursey, 1967). Mounding is a very tedious and expensive operation that limits the scale of root crop production. Yams, for instance, require well pulverized, loose soil consistency with high organic matter levels, for easy penetration and swelling of the tubers (Ezumah, 1986).

Particle size distribution, hydraulic conductivity, bulk density, water holding capacity and pore-size distribution have been reported as the main physical properties of utmost importance to yam cultivation (Orkwor \& Asadu, 1998). Adequate land preparation is, therefore, a pre-requisite to good yam production. 
Ridging has been shown to result in increased sweet potato yields by 38\% (Ennin et al., 2003) over mounding, mainly as a result of increased plant population density and better weed suppression on ridges. Ridging can be mechanized to reduce drudgery and increase the scale of production of root crops.

In the wake of the recent establishment of the President of Ghana's special initiative on cassava starch processing, improved cassava production technologies, including the development of varieties with high starch content between 30-35\%, fertilizer application, and mechanized land and seed bed preparation, need to be introduced to Ghanaian farmers to meet the growing need for cassava as raw material in the starch industry and for other cassava products. The need for mechanization of yam and cassava cultivation cannot, therefore, be over-emphasized. The objectives of the studies were to 1) assess the effect of ridging and mounding on the yield of two popular yam varieties, Dente and Pona in Ghana, 2) assess interactions between seedbed preparation and ecology on yam and cassava yield, 3) quantify tuber yield differences in cassava when planted on ridges, on mounds and on flat ground, and 4) determine interactions between seedbed preparation and fertilizer application on cassava yield.

\section{Cassava study}

\section{Materials and methods}

A cassava seedbed preparation study was undertaken at Fumesua in the forest, and Ejura and Ohawu in the forest-savanna transition agro-ecologies of Ghana in 2004/2005 (Table 1). The experimental design was split plot with three seedbed preparation methods (planting on ridges, planting on mounds, and planting on flat (farmer's practice) as the main plot treatments and fertilizer application rates of 1) 0-0-0, 30-45-90; 2) 6045-90; 3) 90-45-90 kg ha-1 $\mathrm{N}-\mathrm{P}_{2} \mathrm{O}_{5}-\mathrm{K}_{2} 0$ as sub plot treatments. There were three replications at Fumesua and four replications at Ejura. All plots were ploughed and harrowed after which manual ridges and mounds 30$35 \mathrm{~cm}$ high were constructed in rows. Weeds were manually controlled with hoes and cutlasses. Plot size was six rows $10 \mathrm{~m}$ long and cassava spaced at $1 \mathrm{~m}$ row $\times 1 \mathrm{~m}$ within row, one plant/stand for a plant population density of 10,000 plants ha-1. Weeds were cut using quadrants and soil samples taken and oven-dried at 12 weeks after planting, for weed dry matter and soil moisture content assessments.

TABLE 1

Agro-ecological characteristics of the test sites

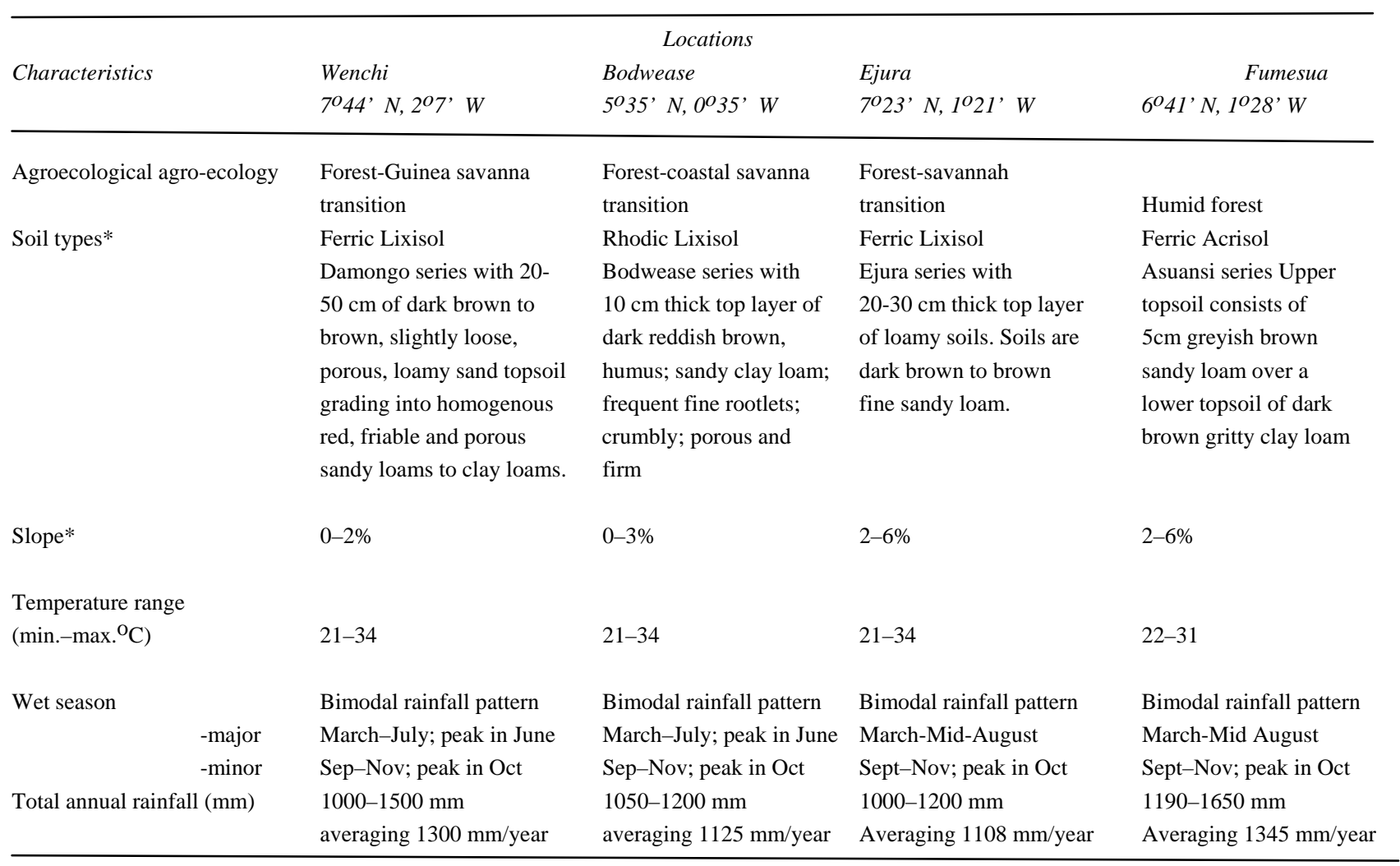

*Adu and Asiamah, 1992. 


\section{Yam study}

The study was a $2^{3}$ factorial experiment conducted in Bodwease in the coastal savanna and Wenchi in the forest-savanna transition agro-ecologies of Ghana (Table 1) in 2003 using RCBD with three replications. The factors were location (Wenchi and Bodwease), variety (Dente and Pona) and seedbed preparation (ridge and mound). Plot size was $10 \mathrm{~m} \times 8 \mathrm{~m}$ with yam spacing of $1 \mathrm{~m} \times 1 \mathrm{~m}$, for a target population of 10,000 plants/ha. Land was ploughed, harrowed and ridges and mounds of $45 \mathrm{~cm}$ high were constructed in rows, $1 \mathrm{~m}$ apart and the plots were mulched. The trials were conducted on fallowed land, under rain-fed conditions with no application of fertilizer or other agro-chemicals. Weeding was manually done average of four times in a cropping season. The yam setts were planted on mounds and ridges and individually staked with bamboo 2-3 $\mathrm{m}$ high. The yam setts were planted at the onset of rains (March-April) with setts weighing $300 \mathrm{~g}$. Data was collected on the six middle rows on disease (leafspots and viruses) incidence and severity and yield and analyzed using ANOVA procedure as per SAS version 9.1.

\section{Cassava study}

\section{Results}

Root yield. At Fumesua (Fig. 1), there was significant interaction $(P \leq 0.05)$ between seedbed preparation method and fertilizer application on fresh cassava root yield. At zero and $30 \mathrm{~kg} \mathrm{~N} \mathrm{ha}^{-1}$, fresh root yield of cassava was significantly higher $(P \leq 0.05)$ for cassava planted on ridge and on flat and least for cassava on mounds. Differences in fresh cassava root yield progressively disappeared with increasing $\mathrm{N}$ rate with no significant differences at $\mathrm{N}$ rate of 60 and $90 \mathrm{~kg} \mathrm{~N} \mathrm{ha}^{-1}$. It appears that on these sandy clay loam soils at Fumesua (Table 1), there was an interaction between applied $\mathrm{N}$ and other soil factors, possibly soil moisture (Table 5), which was higher on ridge and flat than on mounds, making the minimum $\mathrm{N}$ applied more available on ridge and flat than on mound. Ridging across slope is recommended in dry areas for soil and water conservation in crop production (Kumwenda, 1999). Mounding apparently had a greater exposed soil surface area for evapotranspiration and greater weed infestation (Table 5), making weeding most difficult on mounds (Table 4), and possibly contributing to the lower root yields on mounds compared to ridges.

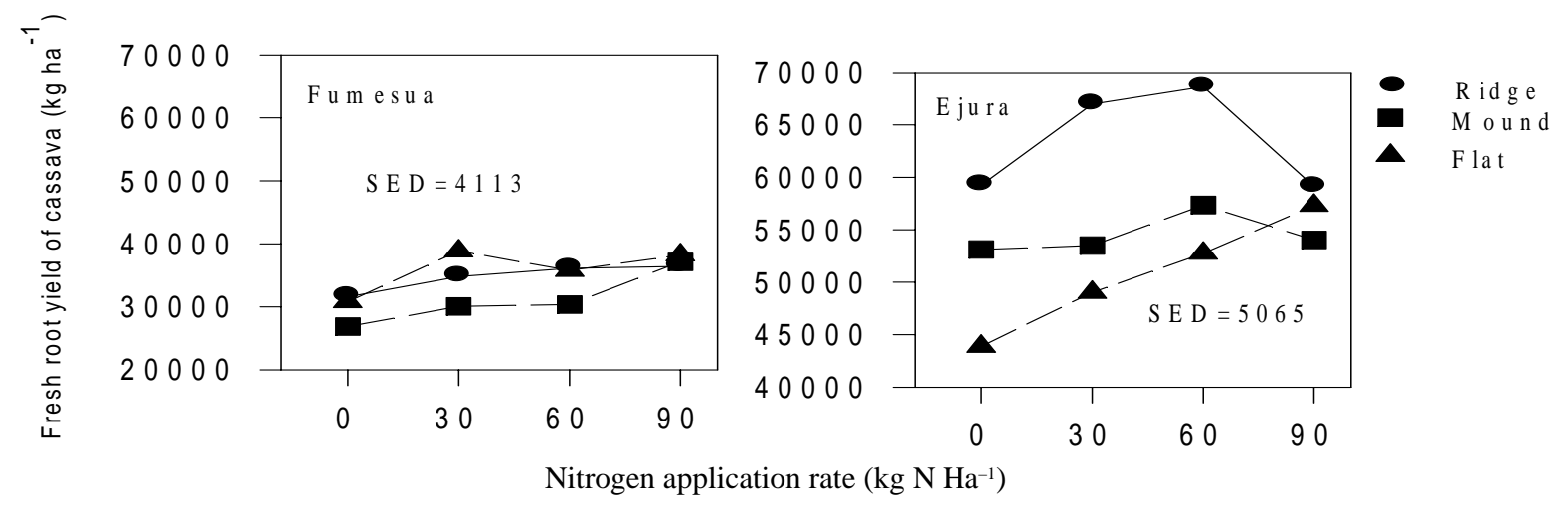

Fig. 1. Fresh root yield of cassava as influenced by seedbed preparation method and fertilizer application method, 2004/2005

Trend in fresh root yield at Ejura was generally different from Fumesua. At Ejura, soils are non-gravelly, well drained sandy loams (Table 1), and cassava root yields were much higher than at Fumesua (Fig. 1). The well-drained sandy loam Lixisols at Ejura apparently favoured development of bigger sized cassava roots (Table 2), leading to higher cassava yields than on the shallow sandy clay loam Acrosols at Fumesua. Lixisols, as are at the Ejura site, have been known (Lal, 1976) to be less weathered and more fertile than Acrisols, as found at the Fumesua site. Planting on ridges resulted in highest cassava root yields at all fertilizer application rates, although differences were not significant at zero $\mathrm{N}$ and at $90 \mathrm{~kg} \mathrm{~N}$. Seed bed preparation method did not affect cassava root yield at $90 \mathrm{~kg} \mathrm{~N} \mathrm{ha}^{-1}$ in both locations. 
TABLE 2

Effect of seedbed preparation method on some agronomic characteristics of cassava at Fumesua and Ejura, 2004/2005

\begin{tabular}{lccccc}
\hline $\begin{array}{l}\text { Treatment } \\
\text { Location }\end{array}$ & $\begin{array}{l}\text { No. of } \\
\text { plants/ha }\end{array}$ & $\begin{array}{l}\text { No. of } \\
\text { roots/ha }\end{array}$ & $\begin{array}{l}\text { No. of } \\
\text { roots/plant }\end{array}$ & $\begin{array}{l}\text { Wt per } \\
\text { root }(\mathrm{g})\end{array}$ & $\begin{array}{c}\text { Plant height } \\
(\mathrm{cm})\end{array}$ \\
\hline $\begin{array}{l}\text { Fumesua } \\
\text { Ridge }\end{array}$ & 8,791 & 69,037 & 7.9 & 492 & 242 \\
Mound & 8,177 & 59,063 & 7.2 & 512 & 222 \\
Flat & 8,333 & 68,151 & 8.1 & 543 & 243 \\
\hline SED & 285.1 & $3,289.50$ & 0.25 & 18.6 & 6.3 \\
\hline Ejura & & & & & \\
Ridge & 10,156 & 57,988 & 5.7 & 1,125 & 172 \\
Mound & 10,585 & 58,008 & 5.5 & 960 & 170 \\
Flat & 10,136 & 52,168 & 5.1 & 1,006 & 6.2 \\
\hline
\end{tabular}

Among other agronomic characteristics, such as better plant growth (Fumesua) and higher weight per root (Ejura), number of roots per plant was found to be significantly higher for ridges in both agroecologies (Table 2), and may be a major contributor to the higher cassava yields on ridges. One of the often reported (Shetto, 1999; Odemerho \& Awunudiogba, 1993; Suyamto \& Howeler 2001) benefits of ridging is its effectiveness in erosion control and high yields of crops.

Odemerho \& Awunudiogba (1993) compared ridging, mounding and flat ground seed bed preparations under monoculture of cassava for reduced soil erosion. They reported that ridging across the slope was the most effective in reducing soil loss, and planting on flat ground was the least effective. The slope of the land appears to affect the effectiveness of ridges to control soil erosion and increase cassava yield. Suyamto \& Howeler (2001), planting cassava on contour ridging on upland slope of $15 \%$, reported that ridging was not more effective than staggered mounding in soil erosion control. However, planting of Vetiver (Vetiveria zizanioides) or elephant grass (Pennissetum purpureum) every $4 \mathrm{~m}$ in addition to contour ridging was necessary for most effective soil erosion control and highest cassava yields. It is apparent from this study that planting cassava on ridges resulted in highest cassava root yields than on mounds and on flat ground, in both the forest and forest-savanna transition agro-ecologies, with sandy clay loams and sandy loams. Increased number of roots per plant was identified as a major contributory factor to the higher yields on ridges.

Root shape. There were no significant interactions between seed bed preparation method and fertilizer application on cassava root shape at both locations. The method of seed bed preparation, however, was significant $(P \leq 0.05)$. Mounding produced slightly more elongated, thinner and generally close to cylindrical cassava roots than planting on ridges and on flat ground, which had more oblong shaped cassava roots, as indicated by the lower root length: diameter ratio values, especially at Fumesua (Table 3).

Ease of management. Ease of manual management of cassava on the various seedbed preparations are shown in Table 6. With the exception of harvesting of cassava which was most difficult on flat ground, all other management practices were easiest on flat ground. Most management practices were most difficult on mounds, except harvesting which was easiest on mounds.

All cassava management practices were intermediate on ridges compared to mounds and flat. There was also a trend for more weed growth on mounds than on ridges (Table 5), and weeding was perceived to be more difficult on mound than on ridges (Table 4). Similar to our findings, Shetto (1999) reported that many farmers find weeding of cassava to be easier on ridges than on mounds. 
TABLE 3

Cassava root shape as influenced by seedbed preparation. Fumesua and Ejura, 2004-2005

\begin{tabular}{lcccc}
\hline $\begin{array}{l}\text { Treatment } \\
\text { Location }\end{array}$ & $\begin{array}{c}\text { Root length } \\
\mathrm{cm}\end{array}$ & $\begin{array}{c}\text { Root diameter } \\
\mathrm{cm}\end{array}$ & $\begin{array}{c}\text { Root circumference } \\
\mathrm{cm}\end{array}$ & $\begin{array}{c}\text { Length : diameter ratio } \\
\mathrm{cm}\end{array}$ \\
\hline $\begin{array}{l}\text { Fumesua } \\
\text { Ridge }\end{array}$ & 25 & 5.1 & 18.9 & 5 \\
Mound & 28.8 & 4.9 & 18.4 & 6 \\
Flat & 26.8 & 5.4 & 19.9 & 5.1 \\
\hline SED & 1.05 & 0.12 & 0.39 & 0.21 \\
\hline Ejura & & & & 4.8 \\
Ridge & 40.6 & 8.4 & 26.9 & 5.1 \\
Mound & 40.9 & 8.1 & 26.2 & 5.1 \\
Flat & 42.1 & 8.3 & 26.5 & 0.14 \\
\hline SED & 1.35 & 0.19 & 0.62 & \\
\hline
\end{tabular}

TABLE 4

Ease of management of cassava on different seedbeds. Fumesua, 2004/2005

\begin{tabular}{lllll}
\hline Type of seed bed & Seed bed preparation & Weeding & Fertilizer application & Harvest \\
\hline \multirow{2}{*}{ Ridge } & & & & \\
Mound & $\dagger 3.0$ & 2.8 & 2.3 & 3.0 \\
Flat & 4.0 & 3.7 & 2.6 & 2.2 \\
\hline \multirow{2}{*}{ SED } & 2.0 & 2.0 & 2.0 & 4.0 \\
N=6 & & & & \\
& 0.01 & 0.13 & 0.15 & 0.1 \\
\hline
\end{tabular}

† Score 1 = very easy; 2 = easy; 3 = difficult; 4 = Very difficult ; 5 = too difficult.

TABLE 5

Weed dry weights, and soil moisture content, 12 weeks after planting. Ejura and Fumesua, 2004

\begin{tabular}{lccc}
\hline Type of seed bed & $\begin{array}{c}\text { Weed dry weightt/ha } \\
\text { Fumesua }\end{array}$ & $\begin{array}{c}\text { Soil moisture content\% } \\
\text { Ejura }\end{array}$ & Fumesua \\
\hline \multirow{2}{*}{ Ridge } & 1.5 & 3.2 & 7.5 \\
Mound & 1.6 & 3.5 & 6.7 \\
Flat & 1.5 & 3.4 & 10.2 \\
\hline SED & 0.106 & 0.22 & 0.69 \\
\hline
\end{tabular}

Yam study

Tuber yield. Location, seedbed prepara-tion and their interaction had no significant effect on leafspot and virus severity, stand at harvest, tuber number per hectare, tuber weight and fresh tuber yield of yams (Table 6). Stand at harvest was generally high ranging from $91.3 \%$ (Pona on ridge) to $100 \%$ (Dente on both ridge and mounds) with a mean of $95.8 \%$. The non-significant locational differences observed can be attributed to the generally similar and favourable edaphic and climatic conditions for yam cultivation prevailing at the two locations (Table 1). Both locations are in the sub-humid areas and boast of Lixisols, which have been reported by Lal (1976), as being widespread in sub-humid and semi-arid regions, and those in sub-humid regions are structurally-active with more favourable physical properties than those in the semi-arid regions.

The non-significant differences observed between mounding and ridging of yams with respect to tuber number per hectare, tuber weight and fresh tuber yield under comparable conditions agree with results obtained by some workers including Brown, (1931) and Onwueme (1978). The trend was, however, in favour of higher yam tuber yields on ridges, although not statistically $(P \leq 0.05)$ significant. If the land is trenched 
before the ridges are constructed, an improvement of yam yield may be obtained, but this is not usually sufficiently great to warrant the additional labour costs in trenching (Brown, 1931).

Varietal differences were observed with respect to stand at harvest, number of tubers per hectare, mean tuber weight and yield of yams (Table 6). Dente had 100\%, 3.4, 16166.7 and 56.1 t/ha for stands at harvest, number of tubers per hectare, mean tuber weight and overall high yields, respectively, compared to 55.1 (98.1\%), 2.1, 13541.7 and 29.3 of Pona (Table 7). Dente, on the average, yielded almost two times the yield of Pona. Dente seed yams often have numerous buds all over the tuber whilst Pona has few buds concentrated in the head region. Sprouting and establishment of Dente is often much greater compared to Pona, which has almost smooth tuber surface, making sprouting very difficult in the latter especially when any part, apart from the head region, is used for planting. Dente is also more vigorous, hardy and forms thicker canopy than Pona, and this might have accounted for the high yield and its parameters recorded for Dente.

TABLE 6

Mean squares values of disease, yield and its components of seedbed preparation and varietal response in two environments (two locations in 1 year) in Ghana

\begin{tabular}{|c|c|c|c|c|c|c|c|}
\hline \multirow[b]{2}{*}{ Source } & \multirow[b]{2}{*}{$d f$} & \multirow[b]{2}{*}{ Leafspot } & \multicolumn{2}{|c|}{ Mean squares } & \multirow[b]{2}{*}{$\begin{array}{c}\text { Number of } \\
\text { tubers per } \\
\text { hectare }\end{array}$} & \multirow[b]{2}{*}{$\begin{array}{c}\text { Mean } \\
\text { tuber weight }\end{array}$} & \multirow[b]{2}{*}{$\begin{array}{c}\text { Fresh tuber } \\
\text { Yield }\end{array}$} \\
\hline & & & Virus & $\begin{array}{c}\text { Stand at } \\
\text { harvest }\end{array}$ & & & \\
\hline loc & 1 & 0.042 & 0.375 & 7.04 & 65340 & 3.36 & 772.62 \\
\hline rep & 2 & 0.875 & 0.292 & 19.41 & 31271.67 & 1.15 & 244.49 \\
\hline Sp & 1 & 0.375 & 0.042 & 0.38 & 73673.33 & 3.01 & 854.95 \\
\hline var & 1 & 1.042 & 0.042 & $145.04^{*}$ & 248063.3* & $9.98 *$ & $4294.35^{* *}$ \\
\hline Loc x var & 1 & 0.042 & 0.375 & 7.04 & 5063.333 & 0.47 & 55.76 \\
\hline Sp x var & 1 & 0.042 & 0.375 & 0.38 & 5063.333 & 0.22 & 26.83 \\
\hline Loc x Sp x var & 2 & 0.042 & 0.375 & 12.04 & 73506.67 & 3.57 & 381.3 \\
\hline
\end{tabular}

NB: Sp = seedbed preparation; var = variety and loc = location

TABLE 7

Effect of seedbed preparation method on Pona and Dente yam varieties at 2 locations in Ghana

\begin{tabular}{|c|c|c|c|c|c|c|c|c|}
\hline Variety & & $\begin{array}{l}\text { ed } \\
\text { ration }\end{array}$ & Leaf spot & Virus & $\begin{array}{l}\text { Stand at } \\
\text { harvest }\end{array}$ & $\begin{array}{c}\text { Mean tuber } \\
\text { weight } \\
(\mathrm{kg})\end{array}$ & $\begin{array}{c}\text { Tuber number } \\
\text { per hectare }\end{array}$ & $\begin{array}{c}\text { Fresh tuber } \\
\text { yield } \\
(\mathrm{t} / \mathrm{ha})\end{array}$ \\
\hline \multirow[t]{3}{*}{ Pona } & & & 1.5 & 1.3 & 55.3 & 1.6 & 12638.9 & 22.2 \\
\hline & & & 1.7 & 1.0 & 54.8 & 2.5 & 14444.4 & 36.3 \\
\hline & & Mean & 1.6 & 1.3 & 55.1 & 2.1 & 13541.7 & 29.3 \\
\hline \multirow[t]{3}{*}{ Dente } & & & 1.2 & 1.3 & 60 & 3.1 & 15638.9 & 51.1 \\
\hline & & & 1.3 & 1.3 & 60 & 3.6 & 16694.4 & 60.9 \\
\hline & & Mean & 1.3 & 1.3 & 60 & 3.4 & 16166.7 & 56.1 \\
\hline \multirow{2}{*}{\multicolumn{2}{|c|}{$\begin{array}{l}\text { Grand mean } \\
\text { SED for vars }\end{array}$}} & - & 1.4 & 1.3 & 57.5 & 89.1 & 450 & 42.6 \\
\hline & & - & 0.3 & 0.2 & 4 & 0.5 & 7.7 & 8.0 \\
\hline
\end{tabular}

Tuber shape. Tuber shape was significantly affected by land/seedbed preparation, even though no yield differences were observed between ridging and mounding. The tubers obtained from mounds were slender and more cylindrical compared to the oblong-shaped tubers obtained under ridged land (Fig. 2 and 3). This result is similar to that obtained in the cassava study (Table 3). Unlike cassava, whose roots penetrate the soil before bulking, in yams, the tuber expands as it is penetrating the soil, hence, the yam tuber shape was more strikingly affected by the seed bed on which it was growing than cassava. In sweet potatoes (Ennin et al., 2003) trend in shape was opposite that of cassava and yams, in that, due to a much higher sweet potato plant population density that could be achieved on ridges, tubers were rather thinner and more cylindrically shaped compared to those on mounds which had wider tuber width and were oblong in shape. 


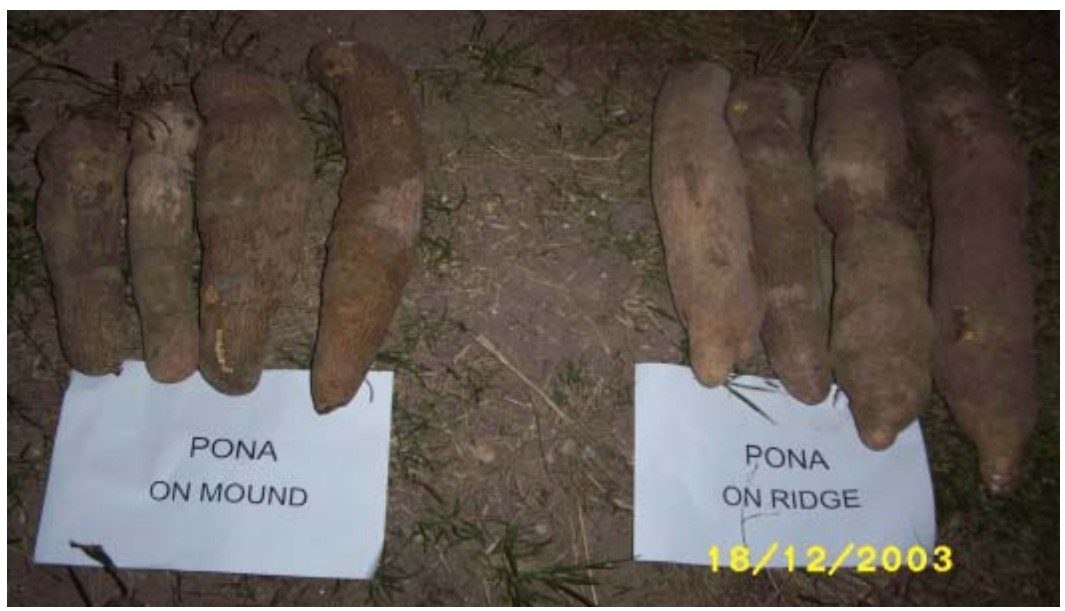

Fig. 2. Effect of seedbed preparation on tuber shape of 'Pona' yam varieties.

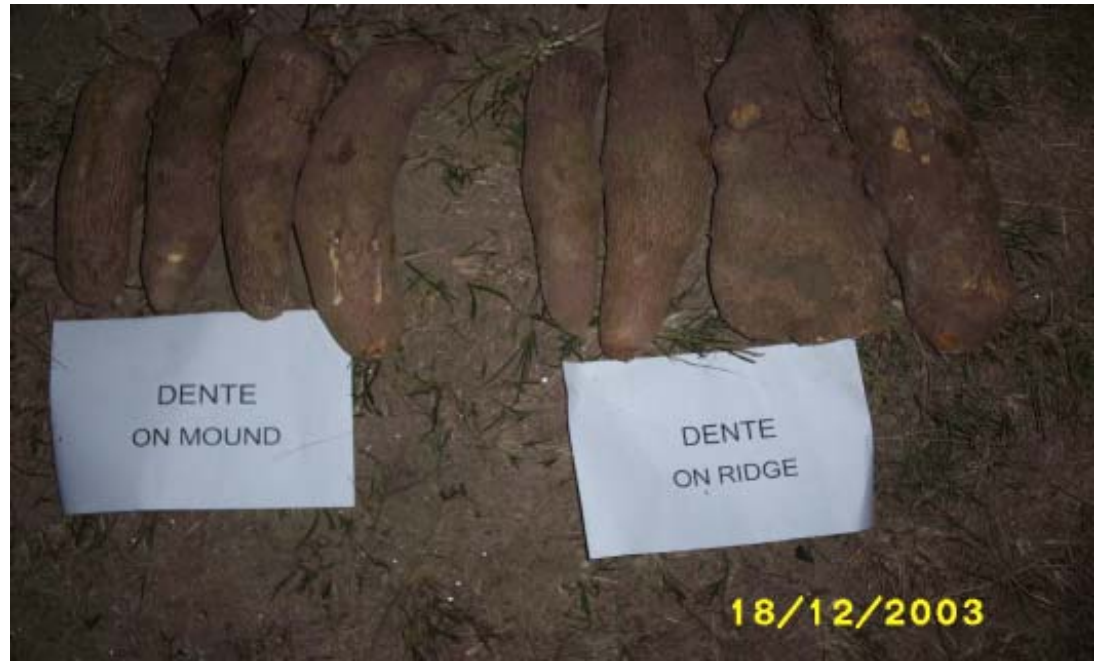

Fig. 3. Effect of seedbed preparation on tuber shape of 'Dente' yam variety.

Ease of management. Generally, the farmers considered manual ridging as more labour intensive than manual mounding for yam production. This is in contrast to the response obtained from construction of seed beds for cassava production where ridging was found to be easier than mounding (Table 4), possibly due to the smaller sizes (30-34 cm high) of the cassava seed beds compared to yam (35-40 cm high). In instances where there are stumps, as is usually the case in yam fields in West Africa, where most farmers shift annually to clear fallowed fields in search of high fertility and stakes, mounding is the farmers' practice. Also, additional labour is required in the building of continuous ridges, which, when compared with mounds, necessitate the moving of substantially greater quantities of earth for yam production (Orkwor \& Asadu 1998). However, in view of the pressure on land and the unsustainabilty of annual shifting cultivation for yam production, absence of stumps will become a feature of modern yam production on old fields with fertilizer application. In the absence of stumps, ridging, unlike mounding, lends itself easily to mechanization (Kumwenda, 1999), and removes the drudgery associated with seed bed preparation and increase the scale of root crop production when mechanized.

Mechanized ridging can be achieved either by animal-drawn ridgers, as is commonly practised in the Guinea savanna agro-ecology of Ghana for cereal and legume production, and in other areas in Africa for cassava and other food crops production (Kumwenda, 1999; Shitto, 2007), or by tractor-mounted ridgers which is a major practice for cassava production in Asian countries (Syamto \& Howeler, 2001). Watananonta et al. (2004) have cautioned that compaction of subsoil ultimately occurs with mechanized seedbed preparation and sub-soiling would be necessary with time before plowing and harrowing for sustained production of high cassava root yields on mechanized ridges.

It is also recommended to cultivate yam, cassava and other root crops on ridges so as to economize space for other crops and to increase the planting density. Moreover, ridges enable the crop to benefit more from rain water retained in the furrows. Ridging is sometimes even necessary with manual cultivation, in order to prevent soil erosion in hilly districts, the ridges being constructed along the contours. Ridging is also 
amenable to improved farming practices such as fertilization (Table 4), herbicide application and staking of yam, due to the regular spacing of crops obtained under this system.

\section{Conclusion}

Planting cassava on ridges resulted in highest cassava root yield, on both sandy clay loam shallow Acrisols in the forest agroecology at Fumesua, and the deep sandy loam Lixisols in the forest-savanna transition agroecology at Ejura, compared to planting on mounds and on flat ground. Increased number of roots per plant was identified as a major contributory factor to the higher cassava yields on ridges. The method of seed bed preparation was, however, not an important determinant of cassava root yield at high rates of fertilizer application of 90-45-90 kg ha-1 N-P $\mathrm{P}_{5}-\mathrm{K}_{2} 0$. Yam yields on mounds and ridges were statistically not different, although trends indicated higher yields on ridges.

The method of seedbed preparation had a significant effect on the root shape of cassava and the tuber shape of yam. Mounding produced slender, close to cylindrically shaped cassava roots and yam tubers, while ridging produced more oblong shaped roots and tubers. Data available indicate clearly that management of cassava fields was easier on manual ridging than on manual mounds, except harvesting which was easier on mounds. Ridging has been shown by this study and others to be a feasible option for cassava and yam production. It has the potential for mechanization to further decrease drudgery and increase the scale of production of cassava and yam production on Lixisols in the forest-savanna transition, coastal-savanna transition agro-ecologies, and Acrisols in the forest agro-ecologies of West-Africa.

\section{Acknowledgement}

The authors will like to acknowledge the technical support from Messrs S. Obeng Antwi, Ebo Blankson, Samuel Tandoh and N. Asamoah Obeng of the CSIR-Crops Research Institute, Kumasi.

\section{References}

Adu S. V. and Asiamah R. D. (1992). Soils of the Ayensu-Densu Basin, Central, Eastern and Greater Accra Regions of Ghana. Council for Scientific and Industrial Research (CSIR) - Soil Research Institute Memoir No. 9. 117 pp.

Asiamah R. D., Mensah C. A. and Nyantakyi P. O. (1993). Report of the detailed soil survey and land evaluation of Wenchi Agricultural Research Station, Brong Ahafo Region, Ghana. Technical Report No. 171.

Brown A. H. D. (1931). Cultivation of yams. 1. Trop. Agric. Trin. 8: 201-206.

Coursey D. G. (1967). Yams. An account of the nature, origins, cultivation and utilisation of the useful members of the Dioscoreaceae. Addison Wesley Longman Ltd, Harlow, U.K. 230 pp.

Ennin S. A., Dapaah H. K. and Asafu-Agyei J. N. (2003). Land preparation for increased sweet potato production in Ghana. Paper presented at the 13th Symposium of the International Society For Tropical Root Crops (ISTRC-World Branch). Held from 10th14th November, 2003 at Arusha, Tanzania. 14 pp.

Ezumah H. C. (1986). Important root crops production systems in southern Nigeria. Paper presented at Seminar on Nigerian Root Culture at the Institute of African Studies, University of Ibadan, Ibadan, Nigeria.

FAO (2000). The state of food insecurity in the world 2000. ISBN 92-5-104479-1 Job No. X8200/E 36 pp

FAO/UNESCO (1964). Definitions, legends and correlation table for soil map of the world. FAO, Rome.

FAOSTAT (2006). FAO Statistics Division 2006.

FAOSTAT (2007). FAO Statistics Division 2007.

Kumwenda W. F. (1999). The role of animal traction in soil water conservation tillage practices among smallholder farmers in Malawi. In Conservation tillage with animal traction. A resource book of the Animal Traction Network for Eastern and Southern Africa (ATNESA). (P. G. Kaumbutho and T. E. Simalenga, ed.) Harare, Zimbabwe. 173 pp.

Lal R. (1976). No-tillage effects on soil properties under different crops in western Nigeria. Soil Sci. Soc. Am. Proc. 40: $762-768$.

Odemerho F. O. and Avwundiogba A. (1993). Effects of changing cassava management practices on soil loss: a Nigerian example. The Geog. J. 159: 63-69.

Onwueme I. C. (1978). The Tropical Tuber Crops. John Wiley and Sons, Chichester, UK. 234 pp.

Orkwor G. C. and Asadu C. L. A. (1998). Agronomy In. Food Yams. Advances in research. (G. C. Orkwor, R. Asiedu and I. J. Ekanayake, ed.), 249 pp. International Institute of Tropical Agriculture, Ibadan, Nigeria. National Root Crop Research Institute, Umuahia, Nigeria.

Suyamto and Howeler R. H. (2001). Cultural practices for soil erosion control in cassava-based cropping systems in Indonesia. In International Erosion Control Association, Ground and water Bioengineering for the Asia-Pacific Region. (D. H. Barker, A. Watson, S. Sombatpanit, B. Northcutt and A. R. Maglinao, ed.) Science Publishers Inc., Enfield, New Hampshire, USA. info@scipub.net

Shetto R. M. (19990. Tillage practices and soil conservation measures in Tanzania. http:/www.fao.org/ag/ages/3ero/Harare/partii/19Sheto.htm

Watananonta W., Tangakul S., Katong S., Phetprapi P., Jantawat S., Samuthong N. and Howeler R. H. (2004). Effect of methods of land preparation on the yields of four cassava cultivars in Thailand. http://www.actahort.org/members/showpdf?booknrarnr=703_28 5/31/2004. 